INTERNATIONAL JOURNAL OF

MULTIDISCIPLINARY STUDIES IN ARCHITECTURE

AND CULTURAL HERITAGE

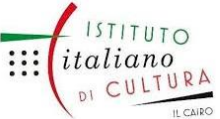

\title{
Comparative Study on the Effect of Sterilization with Essential Oil and Nanosilver on the Chemical Composition of Wood
}

\author{
Shimaa Abd Elhamid Fathy a, Sohaila Alaa Eldain Abdelmawgud a, Hala Khaled Farrag a, \\ Muhammed Akram Abd Elhay a, Sallam Ahmed Sallam a, \\ Rehab Gomaa a, Mourad Fawzy a, *

\begin{abstract}
Fungal damage to wood may be traced to three general causes: (a) lack of suitable protective measures when storing logs or bolts; (b) improper seasoning, storing, or handling of the raw material produced from the log; and (c) failure to take ordinary simple precautions in using the final product. Also bacteria attack the wood but usually, bacteria have little effect on wood properties, except over long periods, but some may make the wood excessively absorptive. This can result in excessive absorption of moisture, adhesive, paint, or preservative during treatment or use. Wooden material is exposed to microbiological attack because of its organic nature and it must be protected because it forms high percentage of our artifacts. Many studies have been done to reach the best method of treatment and one of those methods was the use of essential oils as cinnamon oil, lavender oil, lemon oil, thyme oil and olive oil. The tested oils differed considerably in their efficacy against moulds. Nanoparticles such as silver, titanium and zinc oxide in this study includes application three types of essential oils; lavender oil, lemon oil and thyme oil but the nanomaterials that only silver nano particles that also proved it's efficacy against molds. This study tests it's effect on chemical composition of wood and visual characteristic by FTIR and color change to choose the ideal one at sterilization process. Methods of application varied between direct application to use of vapor of essential oils and direct application at nano material.
\end{abstract}

\begin{tabular}{ll}
\hline Keywords & \\
- & Fungal Damage. \\
- & Artifacts. \\
- & Essential Oils. \\
$-\quad$ & Nanoparticles. \\
$-\quad$ & Molds. \\
\hline
\end{tabular}

\section{Introduction}

Wood is a hygroscopic material which, because of its lignocellulosic nature issusceptible to biological degradation by several micro-organisms such as fungi.Brown rot in wood is caused by basidiomycetes that attack mainly the hemicellulosesand amorphous cellulose in the cell wall (Lykidis, 
Bak, Mantanis, \& Németh, 2016). Wood is a natural, biodegradable, and renewable material that can be used in many applications, including structural members, ornamental objects, aeros pacetechnology.( (Taghiyari, 2014), the nanotechnologies are applied for wood protectionOver the past few decades, nanotechnology was utilized in many sciences and it was used to improve the quality of many materials, including wood and wood-composites. (Taghiyari, 2014). Nanomaterials can also improve the biologicaldurability of wood and wood-composite materials like nano-silver and nano-zinc werealso reported to improve resistance to Trametes versicolor, as a white-rot fungus (Taghiyari, 2014). Bioactive nano-compounds with dimensions of 10 to $100 \mathrm{~nm}$ have specific physical and biological properties. However, their transport to wood islimited by: (1) potential closure of lumens in vessels by tyloses, (2).

dimension of openings in cell walls, and (3) dimension of micro-pores in cell walls (Reinprecht, Vidholdová, \& Gašpar, Decay Inhibition Of Maple Wood With Nano-Zinc Oxide Used In Combination With Essential Oils, 2016) .From the point of view of wood protection, the nanotechnologies are the most important at increasing its photostability (by nano-titanium dioxide and nano-zinc oxide), resistance to fire (by nano-silicon dioxide and nanotitanium dioxide), and resistance to biological pests. Natural resistance of wood against bacteria, moulds, decaying fungi or insects can be increased by nanoparticles of silver, nano-zinc oxide, nano-zinc borate, nanoparticles of copper and nano-copper oxide, or nano-52 titanium dioxide. (Reinprecht, Vidholdová, \& Gašpar, Decay Inhibition Of Maple Wood With Nano-Zinc Oxide Used In Combination With Essential Oils, 2016). Nano-ZnO is able to interact with bacteria,fungi, insects, and other pests, either with the surfaces of a living cell or after penetration to the living cell with its core (Reinprecht, I'zdinsk'y, \& Vidholdov'a, Biological Resistance and Application Properties of Particleboards Containing Nano- Zinc Oxide, 2018). it was found that zinc oxide nanoparticles, used as $0.1-1 \%$ dispersions for treatment of lime and maple woods, suppressed the decay activity of the white-rot fungus Trametes versicolor by up to $56.3 \%$ and the brown-rot fungus Coniophora puteana by up to $39.3 \%$, which on the top surfaces of these wood species partly reduced the activity of the molds Aspergillus niger and Penicillium brevicompactum (Reinprecht, I'zdinsk'y, \& Vidholdov'a, Biological 
Resistance and Application Properties of Particleboards Containing NanoZinc Oxide, 2018).but using of silver nanoparticles as antimicrobial agents has become more common make their production more economical .One of the potential applications of silver is in management of plant diseases. Silver displays multiple modes of inhibitory action against microorganisms; therefore, it may be used with relative safety for control of various plant pathogens, compared to synthetic fungicides. (Kim, et al., 2012). Silvera naturally occurring element in the environment, has had a long history of antimicrobial properties. Silver formulations are used in disinfectants, dishwashers, refrigerators, toilet seats, washing machine tubs, shoe inserts, medical catheter implants and other medical and antibiotic uses (rezaei, Usefi, \& Soltani, 2011). all these mechanisms relate to solvated silver ions, $\mathrm{Ag}+$. The antibacterial properties of any metal come from its ions, which are generated from the neutral metal. In the presence of oxygen, metallic silver can be bactericidal because silver (I) oxide is soluble enough to release free silver ions. it is important to know that antimicrobial activity depends on the extent of the active silver surface. Even all the silver ions in a wood were reduced to silver metal (rezaei, Usefi, \& Soltani, 2011).nanosilver particles were effective at decreasing some types of microorganisms like; $A$. ochraceus, $A$. terrus,$A$. fumigatus, $A$. flavus , $A$. niger, Emericella $\mathrm{sp}$ ,Talaromyces sp, Cladosporum herbarum ,Penicillum simplicissimum , Alternaria alternata, Chaetomium sp, Paecilomyces sp (Ahmed, 2018) . For any nanomaterial The finest nanoparticles are intended to penetrate through the capillaries and bond with the hydroxyl groups of the cellulose content. The larger nanoparticles are intended to penetrate at the appropriate depth and react with the wood polymers (Sahin \& Mantanis, 2011).

It is possible to use essential oils to control plant diseases. Medicinal plants contain substances that are able to play an important role in plant- pathogen interaction, by activating plant defense mechanisms (Lucas, Alves, Pereira, Perina, \& de Souza, 2012). Essential oils have benefits such as they can provide safe and environmentally friendly preservatives. They are effective against bacteria and insects (Bahmani \& Schmidt, 2018). the essential oils are prospective, because they are usually health- friendly and cause only small problems in terms of liquidation of treated products after their servicelife (Reinprecht, Vidholdová, \& Gašpar, Decay Inhibition Of Maple Wood With Nano-Zinc Oxide Used In Combination With Essential Oils, 2016). . Essential oils are complex mixtures of many different aromatic compounds. 
The oil composition is determined mainly by the genetic make-up of each cultivar (Cavanagh \& Wilkinson, 2002). essential oils contain volatile secondary plant metabolites that exhibit insecticidal, antioxidant, antiinflammatory, anti-allergic, and anticancer properties, in addition to their antimicrobial characteristics (Seow, Yeo, Chung, \& Yuk, 2013). Phytochemicals that mostly originate from essential oils, are non- nutritive chemicals with relatively complex structures and have mechanisms different from traditional antimicrobials. They can be categorized into alkaloids, flavanoids, isoflavones, monoterpenes, phenolic acids, carotenoids, etc. In plants, phytochemicalshelp to protect the plant against UV light, herbivores, and pathogens, and also protect from microbes and pollinators (Seow, Yeo, Chung, \& Yuk, 2013). volatile compounds can also repel phytophagous organisms, including virus and phytoplasma vectors, whereas phytoalexins are broad-spectrum antimicrobial metabolites (Rad, et al., 2017). the best anti-fungal efficiency have essential oils in which composition are present: phenolic compounds, such as carvacrol in oregano and savory oils, thymol in thyme oil, eugenol in clove oil, and oxygenated compounds, such as elemol and cinamaldehyde in cinnamon oil. (Reinprecht, Vidholdová, \& Gašpar, DecayInhibition Of Maple Wood With Nano-Zinc Oxide Used In Combination With Essential Oils, 2016). Lemongrass used at wood protection because that holds antidepressant, antioxidant, antiseptic, astringent, bactericidal, fungicidal, nervine and sedative properties (Naik, Fomda, Jaykumar, \& Bhat, 2010). lemongrass is a perennial herb widely cultivated in the tropics and sub-tropics (Naik, Fomda, Jaykumar, \& Bhat, 2010). Lemongrass was found effective against all the test organisms except $P$.aeruginosa. Gram positive organisms were found more sensitive to lemon oil as compared to gram negative organisms (Naik, Fomda, Jaykumar, \& Bhat, 2010). it has the ability to control bacterial growth and fungal pollutants in food, also the antioxidant activity of plant essential oil has been proven. Lavender essential oil is produced, usually by steam distillation, from both the flower heads and foliage,but thechemical composition differs greatly, with the sweeter and most aromatic oil being derived from the flowers (Cavanagh \& Wilkinson, 2002).Lavenders has many types like English and French lavender. The various lavenders have similar ethnobotanical properties and major chemical constituents (Cavanagh \& Wilkinson, 2002). The main constituents of lavender oil are linalool, linalyl acetate, 1,8-cineole, -ocimene (usually both cisand trans-), terpinen-4-ol and camphor. Each 
of these constituents can vary significantly in oils derived from different cultivars with the relative levels of each being the main determinant of market value, application and aroma (Cavanagh \& Wilkinson, 2002). It's vapour has also been shown to inhibit the mycelial growth of Aspergillus fumigatus, however, the effect only lasted until the vapour was removed and Both the oil and oil vapour have been demonstrated to possess some antifungal activity (Cavanagh \& Wilkinson, 2002). Cinnamon is often used for medicinal purposes due to its unique properties. The essential oil from itsbark is rich in trans-cinnamaldehyde with antimicrobial effects against animal and plant pathogens, food poisoning and spoilage bacteria and fungi (Wong, Mudzaqqir, \& Nurdiyana, 2014). It contains antioxidants and other active ingredients which are found in the water-soluble portions of cinnamon, and not the cinnamon oil (Wong, Mudzaqqir, \& Nurdiyana, 2014). more than 300 volatiles were found as constituents of essential oils of cinnamon. It has been established that the oils and extracts from cinnamon possess a distinct antioxidant activity, which is especially attributed to the presence of phenolic and polyphenolic substances (Wong, Mudzaqqir, \& Nurdiyana, 2014). To extract the essential oil, steam distillation and Soxhlet extraction methods were used. Steam distillation is the simplest method to extract the essential oil from cinnamon. (Wong, Mudzaqqir, \& Nurdiyana, 2014).. Thyme oil contain mainly Geraniol, Linalol, Monoterpene Thujanol, Carvacrol, thymol (Vina \& Carol, 2007). thyme essential oil possesses a wide spectrum of fungicidal activity that thyme essential oil presented the strongest inhibitory effect against different pathogenic Candida species among the tested EOs, and the inhibitory zone around the colony obtained with amphotericin $B$ by was smaller than that observed with thyme essential oil (D, J, JP, \& E, 2016). thyme oil activity as one of the most potent against bacteria and yeasts of veterinary importance $(D, J, J P, \& E, 2016)$. the oils from lavender, lemon grass and thyme were the most effective oils for pine wood protection from moulds. This result is not astonishing because the characteristic feature of mouldfungi on wood is their growth restricted to the surfaces and outermost wood regions

.The substrate underneath, in this case beech or pine wood, has no influence because these fungi do not feed from the woody cell wall (Bahmani \& Schmidt, 2018).

The aim of this work was to find anti-microbial of nano-silver in combination with three types of essential oils (lavender oil - thyme oil - lemon oil) at 
vapor case and direct application. The results evaluated by many analysis technique like: FTIR, Color Math and microscopic incpection. Fourier transform infrared spectroscopy (FT-IR) isa useful technique for studying wood decay chemistry [10], as well as to characterize the chemistry of wood [11-13] and determine lignin content in pulp and wood. It is also useful for analyzing chemical and structural changes that occur in wood components due to different treatments ( (Grigore, Voda, \& laşi, 2007). The chromatic characteristics are defined by the colorimetric or chromaticity coordinates: clarity $\left(\mathrm{L}^{*}\right)$, red/green colour component $\left(\mathrm{a}^{*}\right)$, and blue/yellow colour component $\left(\mathrm{b}^{*}\right)$; and by its derived magnitudes: chroma $\left(\mathrm{C}^{*}\right)$, tone $\left(\mathrm{H}^{*}\right)$ and chromacity $\left[\left(a^{*}, b^{*}\right)\right.$ or $\left.\left(C^{*}, H^{*}\right)\right]$. In other words, this CIELab colour or space system is based on a sequential or continuous Cartesian representation of 3 orthogonal axes: $L^{*}, a^{*}$ and $b($ (Oeno, 2006).

\section{Key words:}

(Wood - essential oils - nano - silver - nanomaterials - lavender oil - lemon oil - thyme oil - protection - organisms - microbiology - antifungi - FTIRcolor change -aging)

\section{Material and Methods:}

\subsection{Materials:}

Wood:

wood samples from Aleppo pine (Pinus) those samples dimensions were $3^{\star} 3^{\star} 2 \mathrm{Cm}$ (longitudinal ${ }^{\star}$ radial ${ }^{*}$ tangential) All specimens were defect-free and cut in such a waythat the inclination of the growth rings.

Essential oils:

Three pure essential oils were used in the experiment (Table 1). They for treatment of maple samples there are Lavender oil, lemon oil and thyme oil

Nano silver:

Silver nano particles preparation by chemical reduction method: (5000PPm) silver mitrate $\left(1^{*} 10^{-3}\right.$ molar $) 100 \mathrm{ml}$, polyvinyl pyrrolidone (PVP) $2 \mathrm{gm}$ as a 
INTERNATIONAL JOURNAL OF

MULTIDISCIPLINARY STUDIES IN ARCHITECTURE

AND CULTURAL HERITAGE

capping agent ( nuclear weight 40000), sodium Bo hydrate ( $1^{*} 10^{-3}$ molar $) 10$ $\mathrm{ml}$ as reducing agent

. magnetic stirrer: $400-500 / \mathrm{h}$

Tab. 1 Essential oils and nano siver used in the experiment

\begin{tabular}{|l|l|l|}
\hline Common name & Scientific name & Source \\
\hline Lavaner oil & Lavandula latifolia & National center for research \\
\hline Lemon oil & Citrus Limonum & National center for research \\
\hline Thyme oil & \multicolumn{1}{|c|}{ Thymus vulgaris } & National center for research \\
\hline Nano silver & AgNPs & $\begin{array}{l}\text { Cairo university center of } \\
\text { nano }\end{array}$ \\
\hline
\end{tabular}

\subsection{Treatment methods:}

The samples of wood were dried at ISO 5630-3:1996 standard. $-80^{\circ} \mathrm{C}$ and $65 \%$ RH for 5 days $=25$ years. Binder dry oven with digital indicator, model no. 92403000002000 .

Treatment by essential oils done by two methods

a. Direct method: by using the brush directly with the oil

b. Indirect method: at this method modern method used that glass box contains two parts, base that put on it the peakier or petri dish contains the essential oil and the middle part that the object put on it. This method depends on vapor of oils that inside the box, it was experimented the essential oils for 5 days and for 10 days

Treatment by nano material:

The use of nano silver was done by only one method that the direct method by usingbrushes.

Analysis and investigation: 
INTERNATIONAL JOURNAL OF

MULTIDISCIPLINARY STUDIES IN ARCHITECTURE

AND CULTURAL HERITAGE

Microscopic inspection. ROHAS Digital Microscope 1000X.

Colorimetric measurements. Mini Scan-EZ MSEZO693. (CIE Lab)

FTIR. Nicolet 380 FT-IR Spectrometer. Solid Sample -Bromide Technique.

Table 2 Assignment of the IR bands of functional groups in wood

\begin{tabular}{|l|l|}
\hline Band position $(\mathrm{cm}-1)$ & Functional group \\
\hline $3450-3400$ & $\mathrm{O}-\mathrm{H}$ alcohol \\
\hline $2930-2910$ & $\mathrm{C}-\mathrm{H}$ methyl and methylene groups \\
\hline $1740-1730$ & $\mathrm{C}=\mathrm{O}$ carbonyls \\
\hline $1640-1618$ & $\mathrm{C}=\mathrm{C}$ alkene \\
\hline $1515-1504$ & $\mathrm{C}=\mathrm{C}$ aromatic \\
\hline $1462-1425$ & $\mathrm{CH} 2$ cellulose, lignin \\
\hline $1384-1346$ & $\mathrm{C}-\mathrm{H}$ cellulose, hemicellulose \\
\hline $1260-1234$ & $\mathrm{O}-\mathrm{H}$ phenolic \\
\hline $1170-1153$ & $\mathrm{O}-\mathrm{H}$ alcohols \\
\hline 910 & $\mathrm{C}=\mathrm{C}$ alkenes \\
\hline
\end{tabular}

( ( Ghica, Alley, \& laşi, 2007)

\section{Results and Discussion:}

The experiments were designed in an attempt to compare between the effect ofessential oils by direct and indirect method and nanosilver by direct method This was achieved using three investigation and analysis: FTIR, colorimetric measurement, microscopic inspection.

1.1. microscopic inspection

revealed that effect of treatment on the surface before and after aging process on lavender oil no visual changes even before or after aging at direct application by brushalso at indirect method even for five or ten days no visual changes can be recognized by naked eyes. At thyme oil direct application even before or after aging it caused visual color change can be noticed by naked eyes also at indirect method but at ten days on vapor method but after aging but five days on vapor method no visual changes occurred even before or after aging. At lemon oil was the worst at direct application that caused visible color change even before or after aging but no recognizable changes at indirect method before or after aging or five and ten days. In case of nanosilver particles that applied only by direct method revealed that no 
visual color changes occurred even before or after aging process.

1. lavender oil:
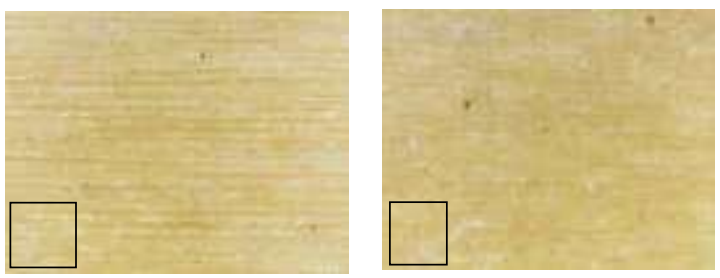

Figure $A$ the direct application of the lavender oil before aging. Figure $B$ the direct application of lavender after aging. From this we can reveal that visible small visual change on direct application of lavender
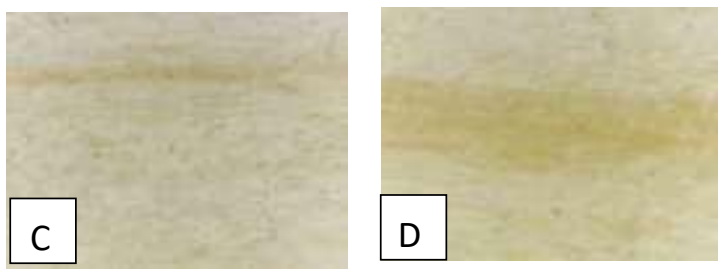

Figure $C$ the indirect application by using vapor of the lavender oil for five days before aging. Figure $D$ the indirect application by using vapor of lavender oil for five days after aging. That revealed no visual changes can be noticed by naked eyes.
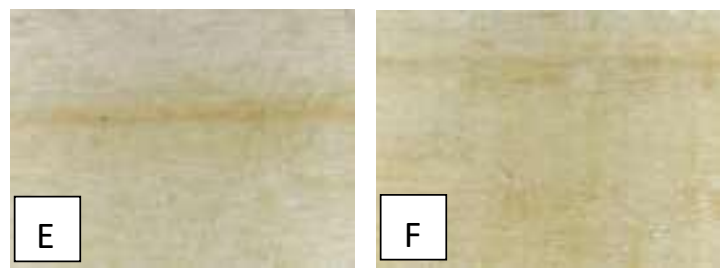

Figure $\mathrm{E}$ the indirect application by using vapor of lavender oil for ten days before aging. Figure $\mathrm{F}$ indirect application by using vapor of lavender oil for ten days after aging. That revealed no visible visual change can be noticed by naked eyes. 


\section{1.thyme oil:}
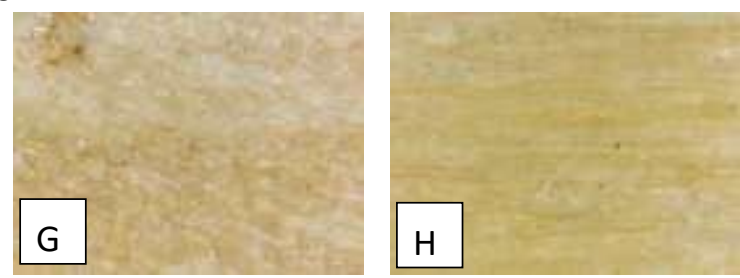

Figure $\mathrm{G}$ the direct application of thyme oil before aging. Figure $\mathrm{H}$ direct application of thyme oil after aging.That revealed it cause visible visual change even before or after aging process.

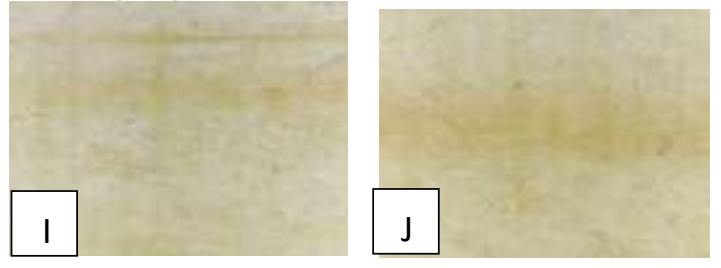

Figure I the indirect application of thyme oil by using vapor of oil for five days beforeaging. Figure $\mathrm{J}$ the indirect application for five days after aging. That revealed no visible visual change can be noticed by naked eyes.

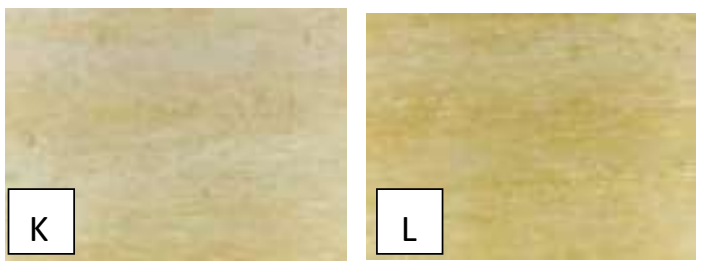

Figure $\mathrm{K}$ indirect application of thyme oil by using the vapor of oil for ten days beforeaging. Figure $L$ the indirect application for ten days after aging. That revealed starting of visual changes before aging and after aging it became clear and can be noticed by naked eyes.

1.lemon oil:
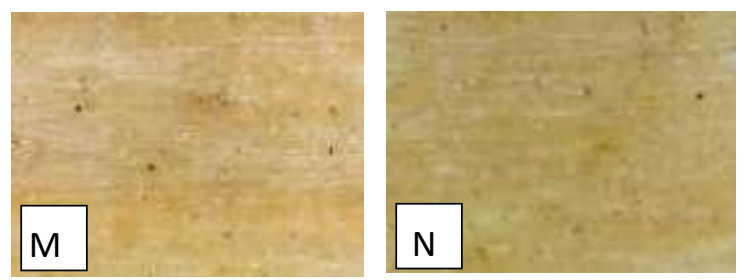

Figure $\mathrm{M}$ the direct application of lemon oil before aging. Figure $\mathrm{N}$ the direct 
application of lemon oil after aging. That revealed massive visual changes evenbefore or after aging.

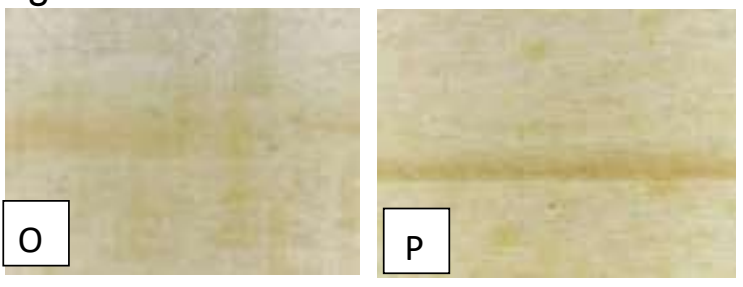

Figure $O$ the indirect application of lemon oil for five days in the vapor of oil before aging. Figure $P$ the indirect application for five days on vapor after aging. That revealed no visual changes before aging it starts with aging.
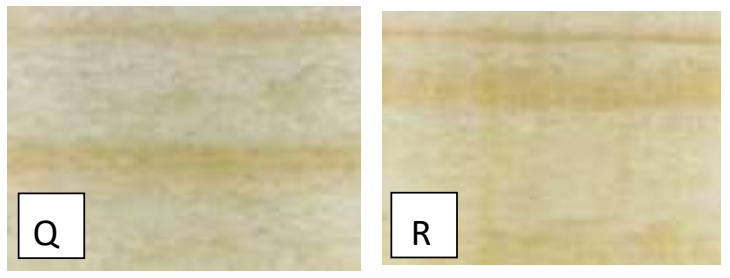

Figure $Q$ indirect application of oil by using the vapor of it for ten days before aging. Figure $\mathrm{R}$ indirect application for ten days after aging. That revealed changes starts with aging.

1.nanosilver:
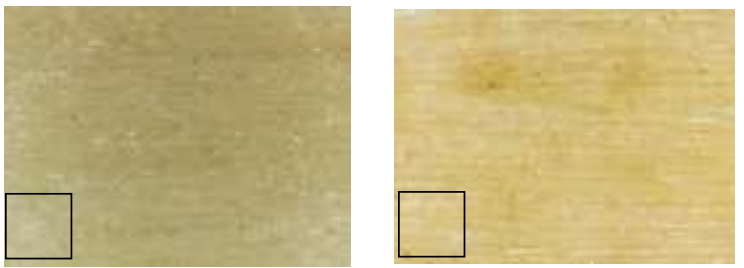

Figure $S$ nanosilver application by direct method before aging. Figure $T$ direct application of nanosilver after aging. That revealed no visual changes just allowed changes.

\subsection{Colorimetric measurement}

The surface color of specimens exposed to artificial weathering for different periods was measured using a reflectance spectrophotometer with a measuring head whichhas a diameter of $10 \mathrm{~mm}$. Equipment calibration was 
carried out with standards provided by the supplier. The color system $L^{*} a^{*} b^{*}$ 1976 according to the CIELab (Commission International ed'éclairage) standard was used to determinate color modifications. The system is characterized by three parameters, $L^{*}, a^{*}$, and $b^{*}$ co- ordinates that represent the color pairs red/green and yellow/blue, respectively. The total color difference $(\Delta E)$ was calculated as a function of the artificial sunlight exposure time ( (Kocaefe, Huang, Kocaefe, \& Boluk, 2013).

Table 3: value of $\Delta \mathrm{E}$

\begin{tabular}{|c|c|c|c|c|}
\hline Sample & $\mathrm{L}$ & $\mathrm{A}$ & $B$ & $\Delta \mathrm{E}$ \\
\hline S18 & 85.24 & 2.16 & 18.06 & \\
\hline L1 & 79.24 & 4.51 & 24.22 & 5.46 \\
\hline L2(4) & 83.64 & 2.66 & 19.63 & 1.42 \\
\hline L3(23) & 76.19 & 2.50 & 19.15 & 6.25 \\
\hline M22 (1) & 81.07 & 3.67 & 22.50 & 3.83 \\
\hline M2(16) & 84.27 & 2.37 & 18.98 & 0.83 \\
\hline M3(17) & 83.85 & 2.81 & 19.80 & 1.44 \\
\hline
\end{tabular}


INTERNATIONAL JOURNAL OF

MULTIDISCIPLINARY STUDIES IN ARCHITECTURE AND CULTURAL HERITAGE

\begin{tabular}{|c|c|c|c|c|}
\hline $\mathrm{Z14}(1)$ & 81.21 & 3.20 & 21.31 & 3.31 \\
\hline Z2(24) & 84.34 & 2.48 & 19.57 & 1.04 \\
\hline Z3(2) & 81.71 & 3.64 & 22.16 & 3.41 \\
\hline N9 & 83.64 & 2.61 & 19.12 & 1.28 \\
\hline
\end{tabular}

$\mathbf{L}$

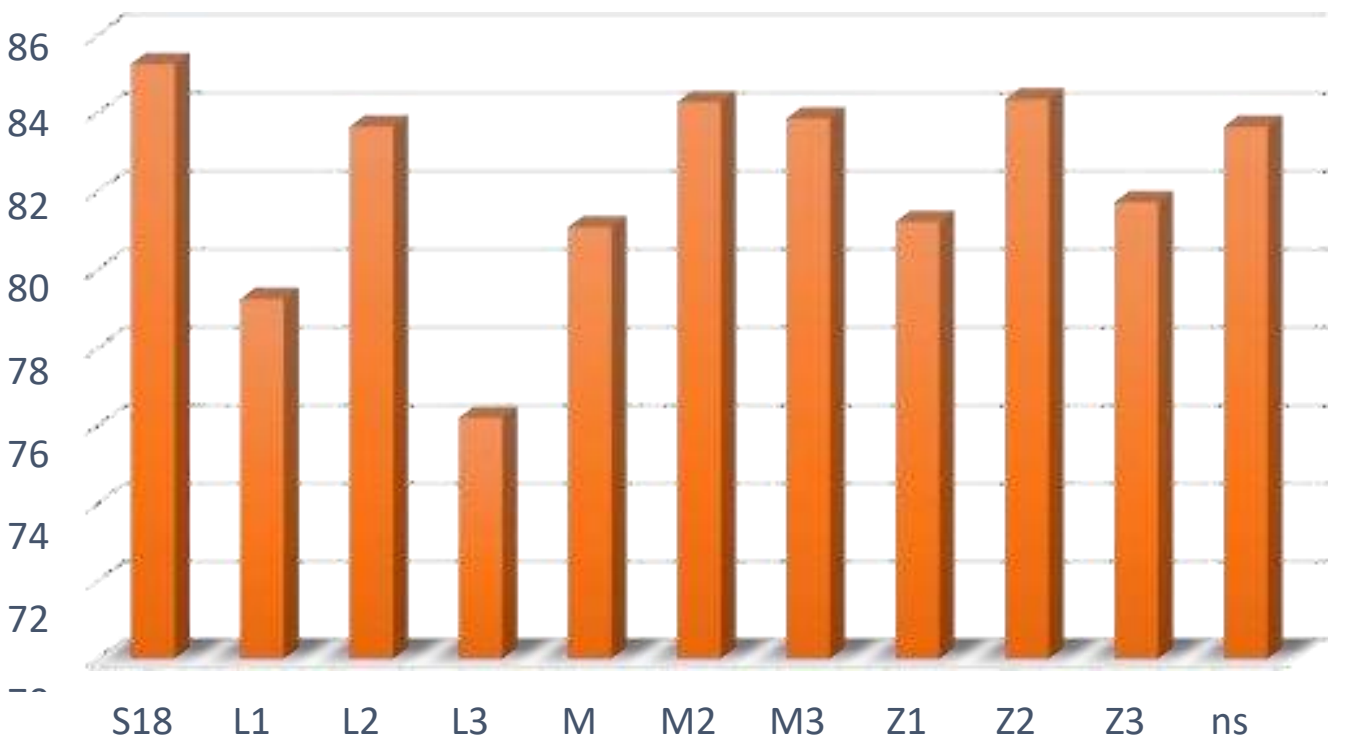

Fig. 1. ratio of $L$ at all samples compared to the standard sample 


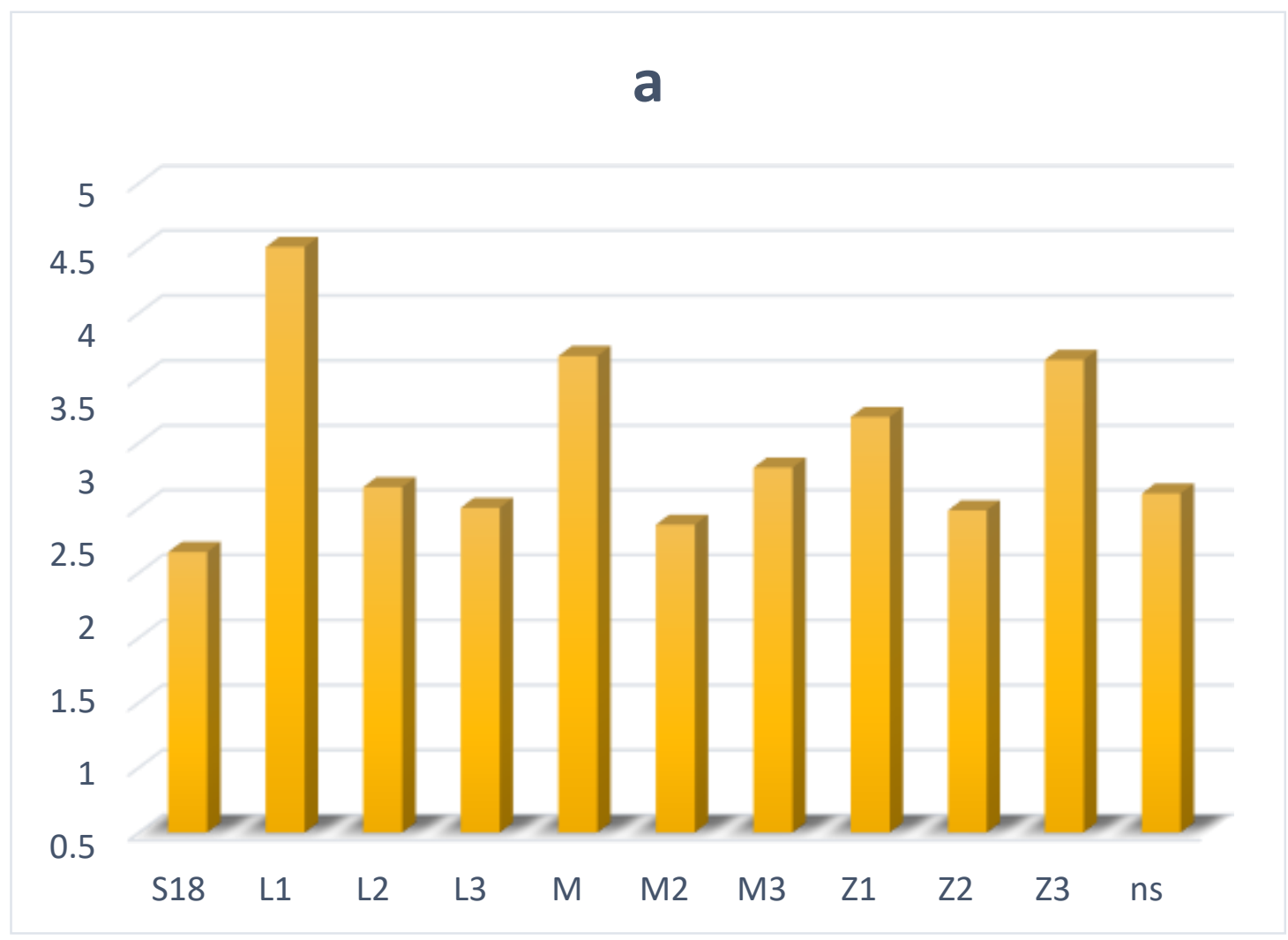

Fig. 2. Ratio of a at all samples compared to the standard sample. 
INTERNATIONAL JOURNAL OF

MULTIDISCIPLINARY STUDIES IN ARCHITECTURE

AND CULTURAL HERITAGE

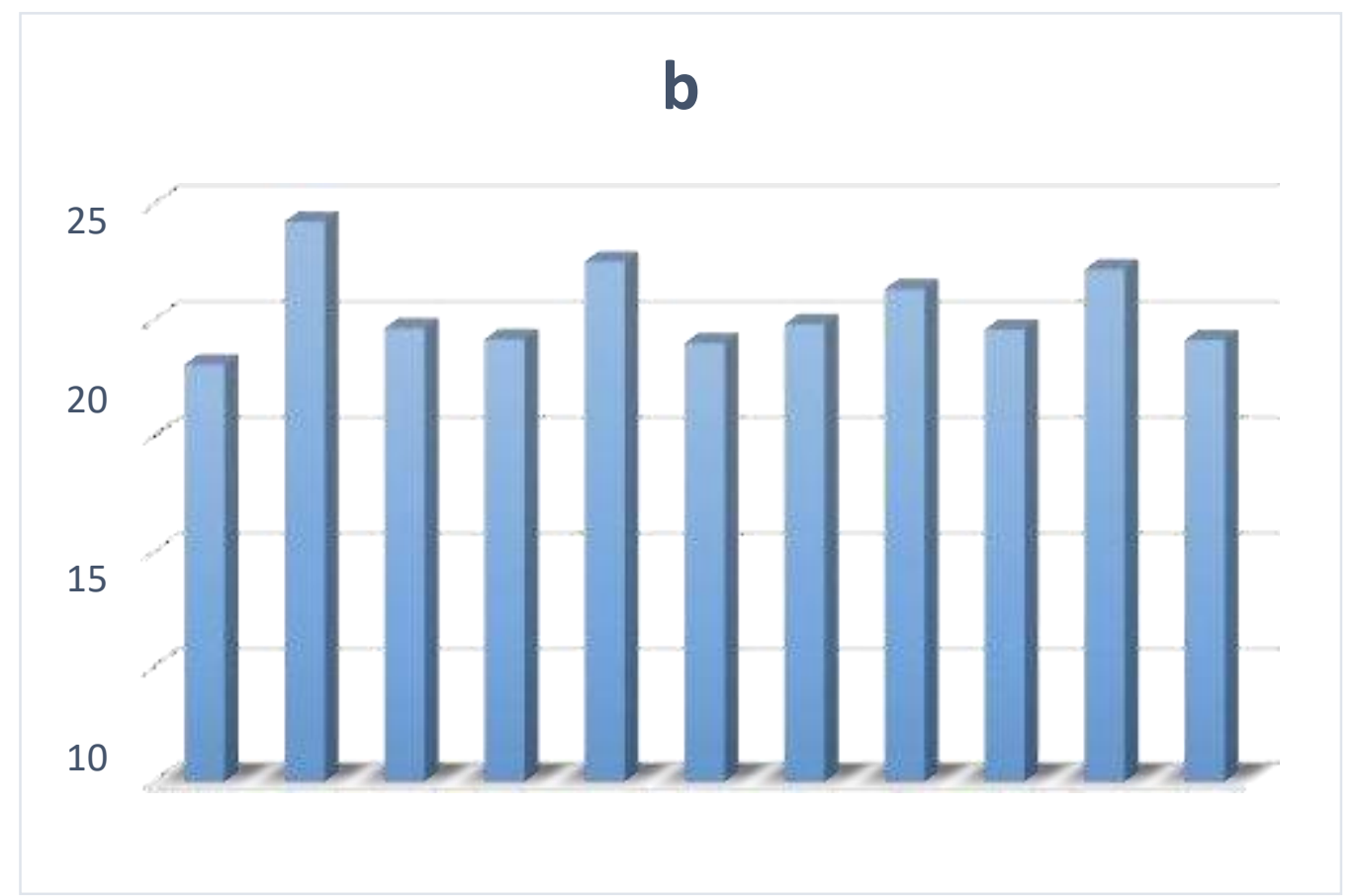

Fig. 3. Ratio of $b$ at all samples compared to standard

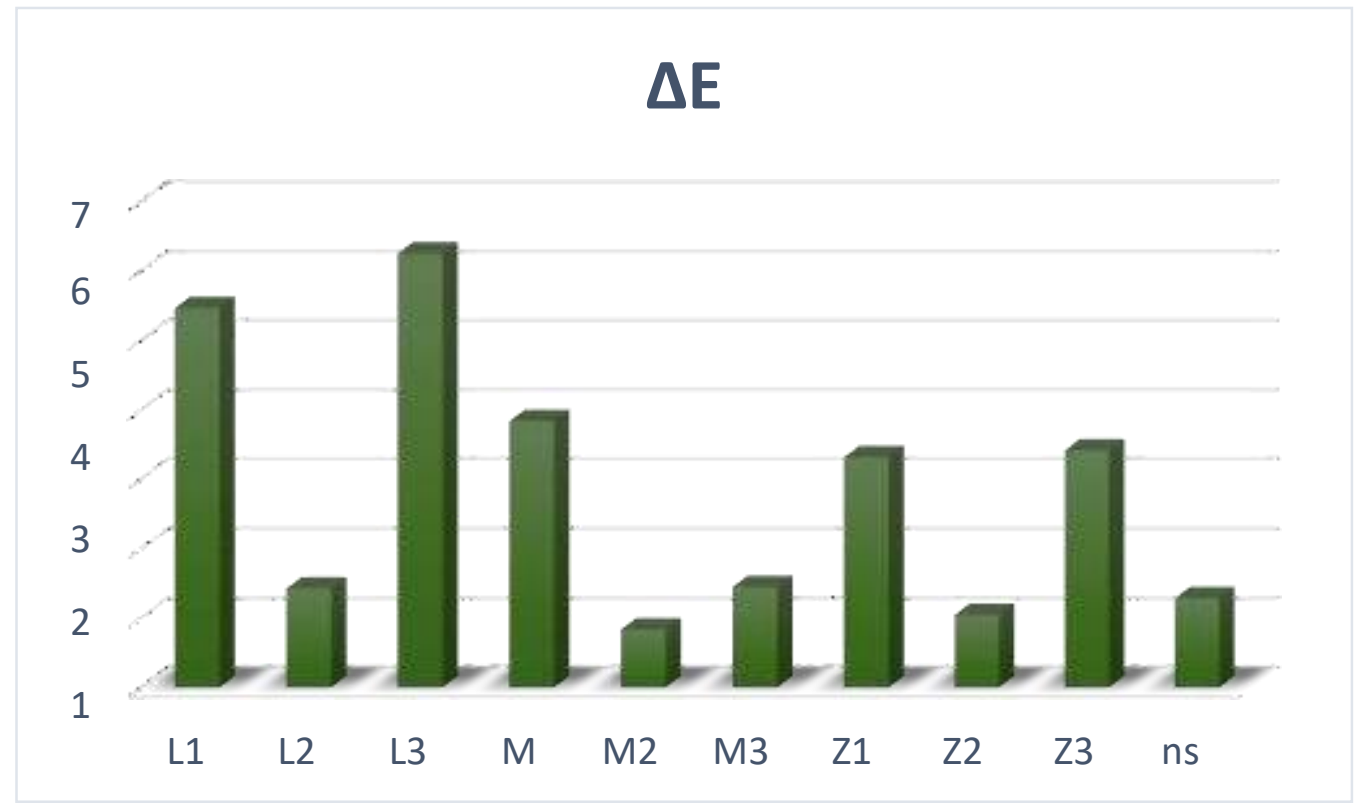


The color system $\mathrm{L}^{*} \mathrm{a}^{*} \mathrm{~b}^{*}$ according to the CIELab standard was used to determinate color modifications at all samples The total color difference $(\Delta E)$ was calculated showing direct application at all types of oils caused the highest changes especially at the lemon oil that record the highest changes by indirect method changes increased with more days of treatment that reveal it is instability, lavender oil caused the lowest changes especially at five days treatment by indirect method and also the least rate of changes by age, nanosilver cause the lowest rate of changes compared to lavender for ten days indirect application but thyme oil changes occurred after ten days on The color system $\mathrm{L}^{*} \mathrm{a}^{*} \mathrm{~b}^{*}$ according to the CIELab standard was used to determinate color modifications at all samples The total color difference $(\Delta E)$ was calculated showing direct application at all types of oils caused the highest changes especially at the lemon oil that record the highest changes by indirect method changes increased with more days of treatment that reveal it is instability, lavender oil caused the lowestchanges especially at five days treatment by indirect method and also the least rate of changes by age, nanosilver cause the lowest rate of changes compared to lavender for ten days indirect application but thyme oil changes occurred after ten days on vapor of oil , small changes at five days on vapor and highest changes for this oil on directapplication that revealed it is instability.

1.1. Color math:

\section{Lavender oil:}

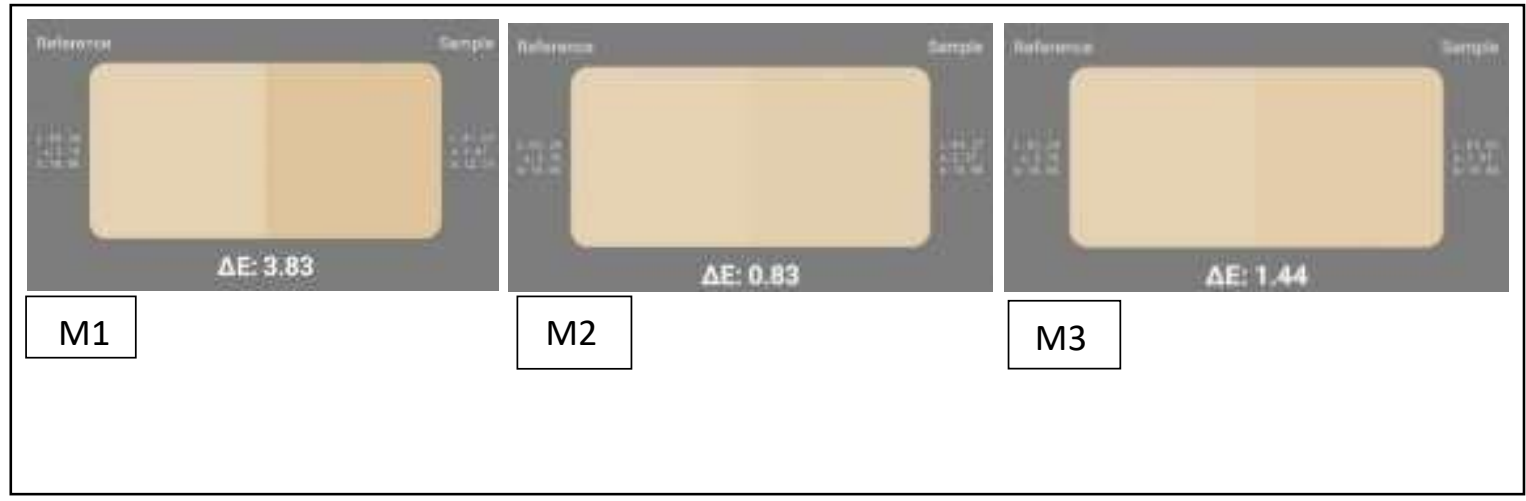


INTERNATIONAL JOURNAL OF

MULTIDISCIPLINARY STUDIES IN ARCHITECTURE

AND CULTURAL HERITAGE

Thyme oil:

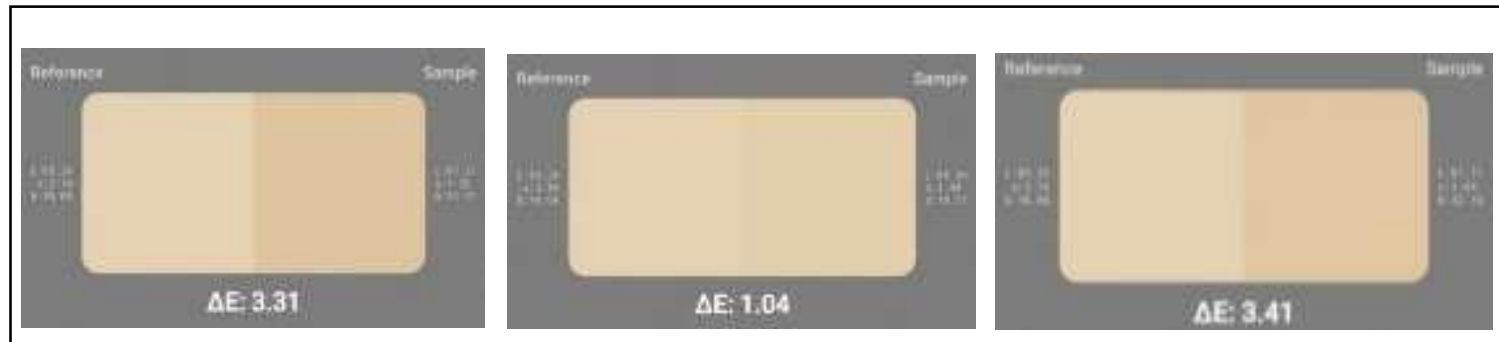

Z1. Direct application, Z2 indirect application for five days and Z3. Indirect application for ten days

\section{Lemon oil:}

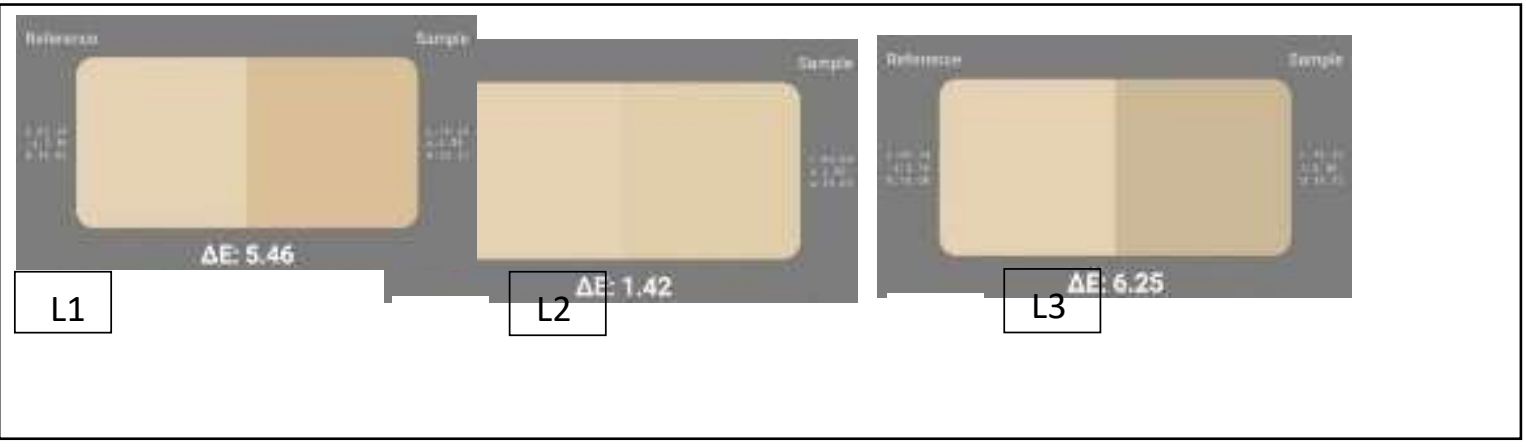

nanosilver:

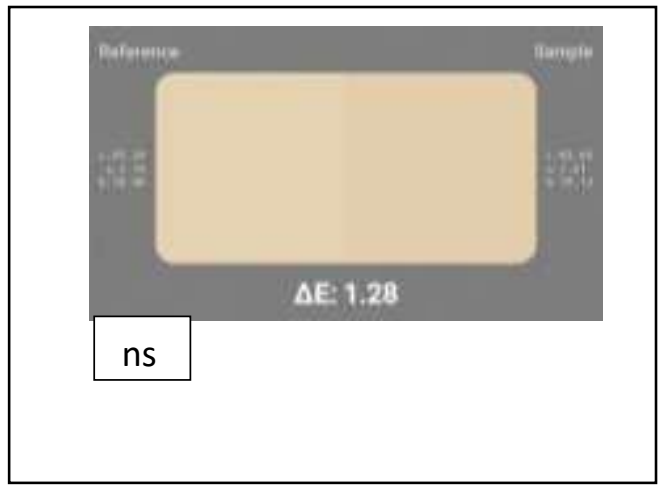




\subsection{Fourier transform infrared spectroscopy (FT-IR)}

is a useful technique for studying wood decay chemistry [10], as well as to characterize the chemistry of wood and determine lignin content in pulp and wood. It is also useful for analyzing chemical and structural changes that occur in woodcomponents due to different treatments. ( (Grigore, Voda, \& Iaşi, 2007). FTIR analysis and microscopy - measurement principle In FTIR analysis, a sample is subjected to IR radiation. Specific parts of the IR spectrum are absorbed by the sample according to its chemical composition The stretch and deformation vibrations of specific molecular bonds in the sample, for example $\mathrm{C}-\mathrm{H}, \mathrm{O}-\mathrm{H}, \mathrm{N}-\mathrm{H}, \mathrm{C}=\mathrm{O}$, etc., result in absorption bands at specific wavenumbers of the FTIR spectrum. Wavenumber expressed in $\mathrm{cm}-1$ is the traditional unit for FTIR analysis. Wavenumber is inversely related to wavelength as expressed by the following equation: Wavenumber $(\mathrm{cm}-1)=107 /$ wavelength $(\mathrm{nm})$. Wavenumber is proportional to frequency and thus to energy ( Naumann \& Kües, 2007). FTIR spectroscopy has been used as a simple technique for obtaining rapid information on the structure of wood constituents and chemical changes taking place in wood due to various treatments. In contrast to conventional chemical analysis, this method requires small sample sizes, short analysis time, and does not destroy the wood structure( ( Poletto, Zattera, \& Santana, 2012). 
INTERNATIONAL JOURNAL OF

MULTIDISCIPLINARY STUDIES IN ARCHITECTURE

AND CULTURAL HERITAGE

Table 4. Assignments of characteristic absorption IR bands of wood samples infingerprint region.

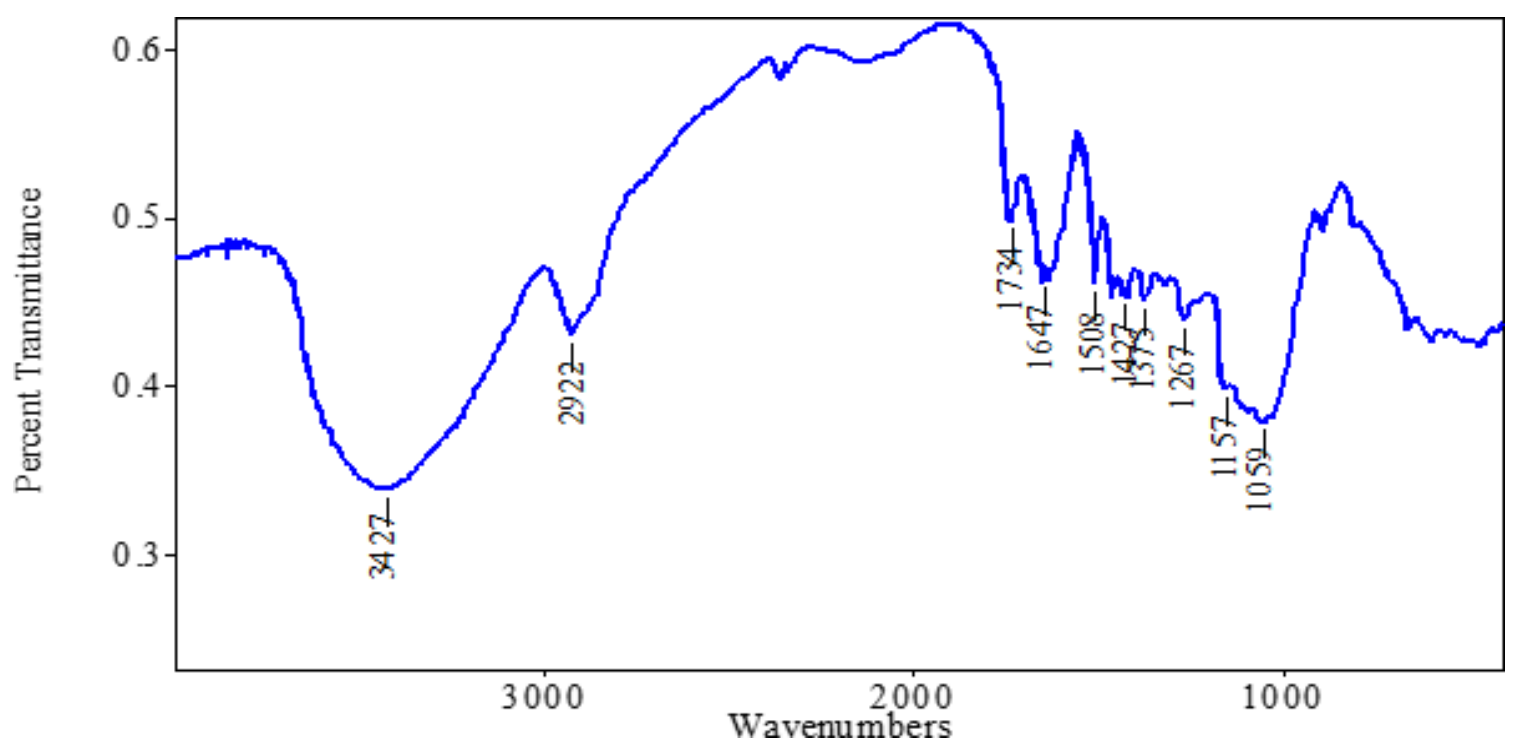

Figure (5) shows the standard sample

\begin{tabular}{|c|c|c|}
\hline Wavenumber $(\mathrm{cm}-1)$ & Functional group & Assignment \\
\hline 3427 & $\mathrm{OH}$ stretching & Cellulose \\
\hline 2922 & $\mathrm{CH}$ stretching & Cellulose \\
\hline 1734 & $\begin{array}{l}\mathrm{C}=\mathrm{O} \text { stretching in } \\
\text { unconjugated } \\
\begin{array}{c}\text { ketones aldehydes } \\
\text { and carboxyl }\end{array}\end{array}$ & Xylan and hemicellulose \\
\hline 1647 & $\begin{array}{ll}\mathrm{C}=\mathrm{C} & \begin{array}{l}\text { stretching of } \\
\text { the aromatic ring }\end{array}\end{array}$ & Lignin \\
\hline 1508 & $\mathrm{C}=\mathrm{C} \begin{array}{l}\text { stretching of } \\
\text { the aromatic ring }\end{array}$ & Lignin \\
\hline
\end{tabular}


INTERNATIONAL JOURNAL OF

MULTIDISCIPLINARY STUDIES IN ARCHITECTURE

AND CULTURAL HERITAGE

\begin{tabular}{|l|l|l|}
\hline 1427 & CH2 bending & $\begin{array}{l}\text { Cellulose (crystallised I } \\
\text { and } \\
\text { amorphous) }\end{array}$ \\
\hline 1375 & CH bending & Cellulose \\
\hline 1267 & CO stretching & $\begin{array}{l}\text { Lignin and } \\
\text { hemicellulose }\end{array}$ \\
\hline 1157 & $\begin{array}{l}\text { COC asym. bridge } \\
\text { oxygen stretching }\end{array}$ & Cellulose \\
\hline 1059 & $\begin{array}{l}\text { asym. Out of phase ring } \\
\text { stretching }\end{array}$ & Cellulose \\
\hline
\end{tabular}

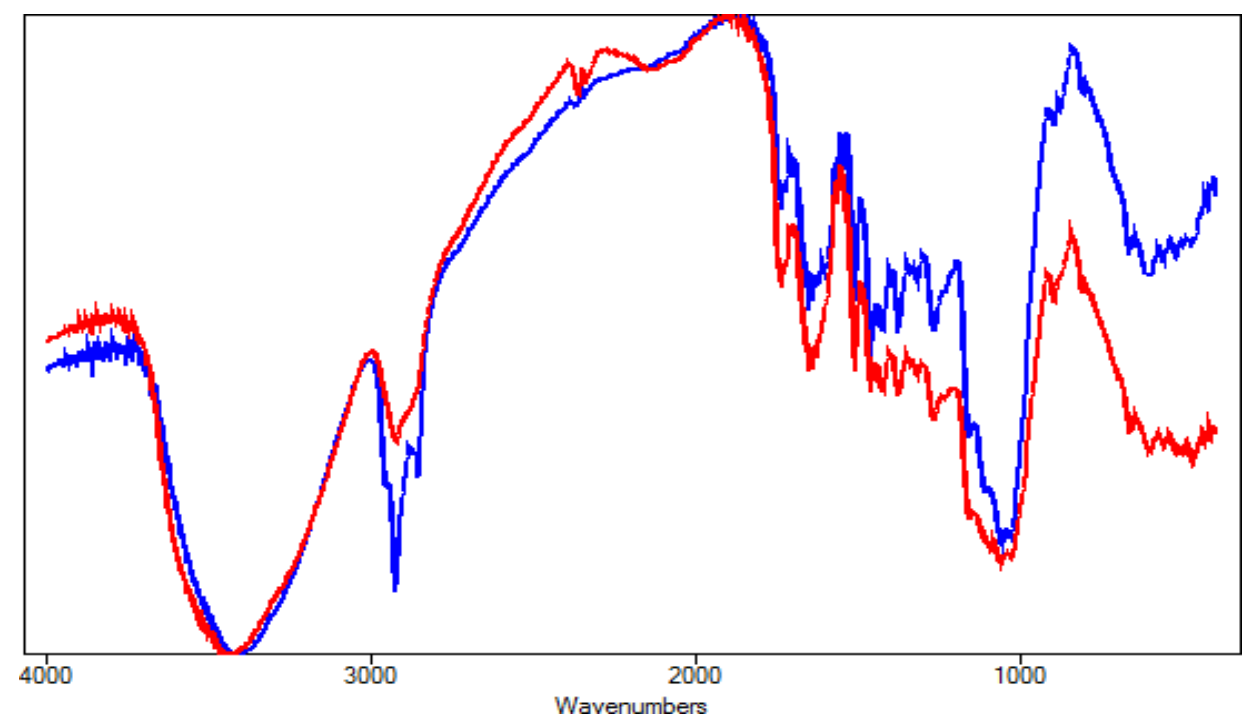


Figure (6) FT-IR spectra of wood sample treated by lemon oil with direct application that revealed simple decreasing at hemicellulose ,oxidation of cellulose and $\mathrm{CH}$ stretching by increasing.

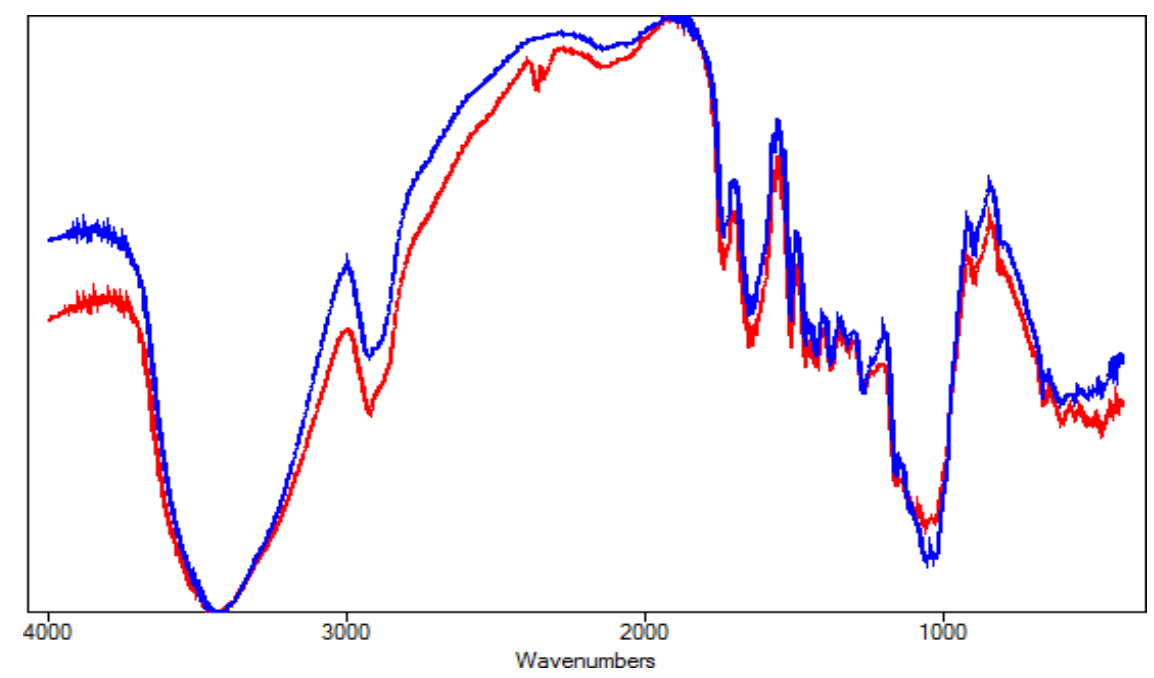

Figure (7) FT-IR spectra of wood sample treated by lemon oil with indirect application for five days that revealed no changes just increasing at polymerization of cellulose

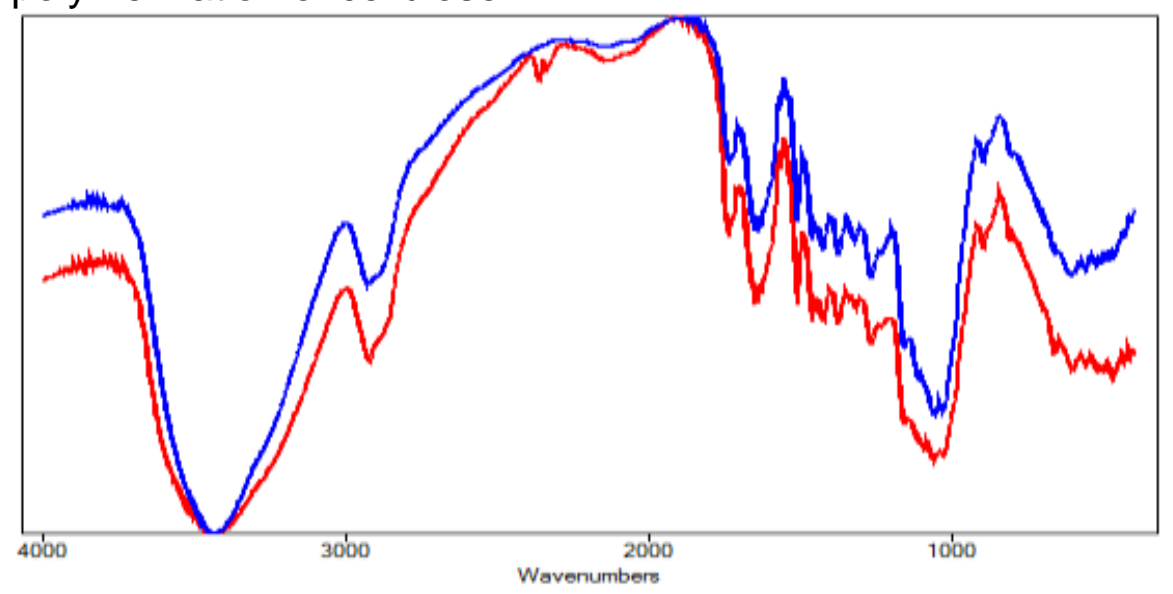


Figure (8) FT-IR spectra of wood sample treated by lemon oil with indirect application for ten days that revealed simple changes at $\mathrm{OH}$ stretching it refers to simple loss at water content and moderate changes at hemicellulose, oxidation and polymerization by losing

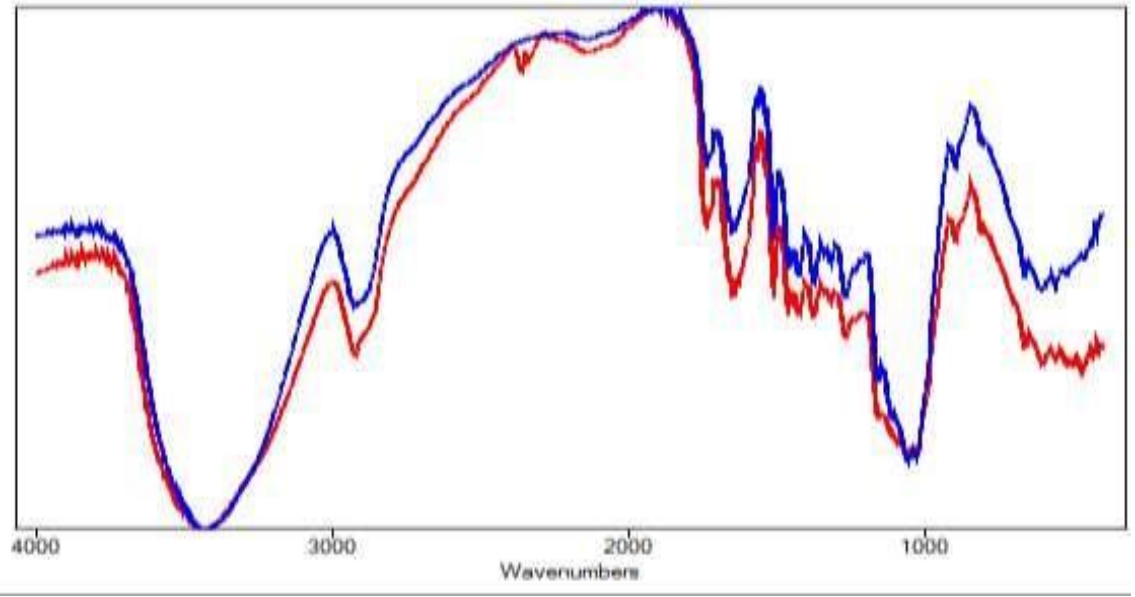

Figure (9) FT-IR spectra of wood sample treated by lavander oil with direct application that revealed changes at $\mathrm{CH}$ stretching, hemicellulose and oxidation of cellulose by losing

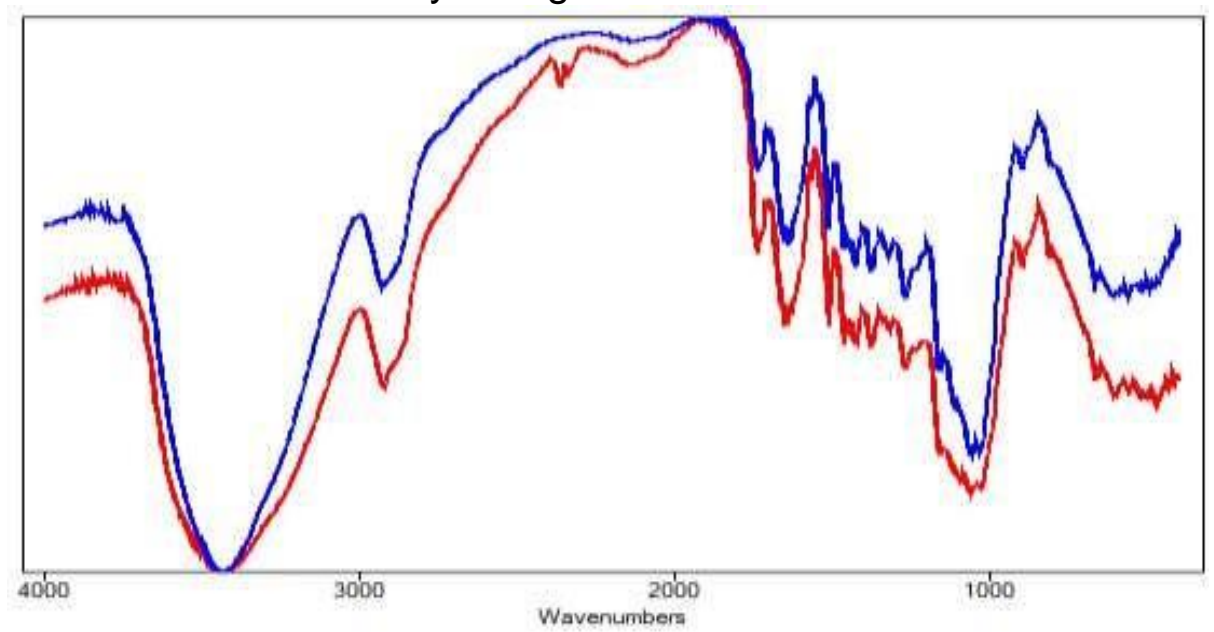


Figure (10) FT-IR spectra of wood sample treated by lavander oil with indirect application for five days that revealed loss at water content according to $\mathrm{OH}$ stretching and decreasing at oxidation of cellulose

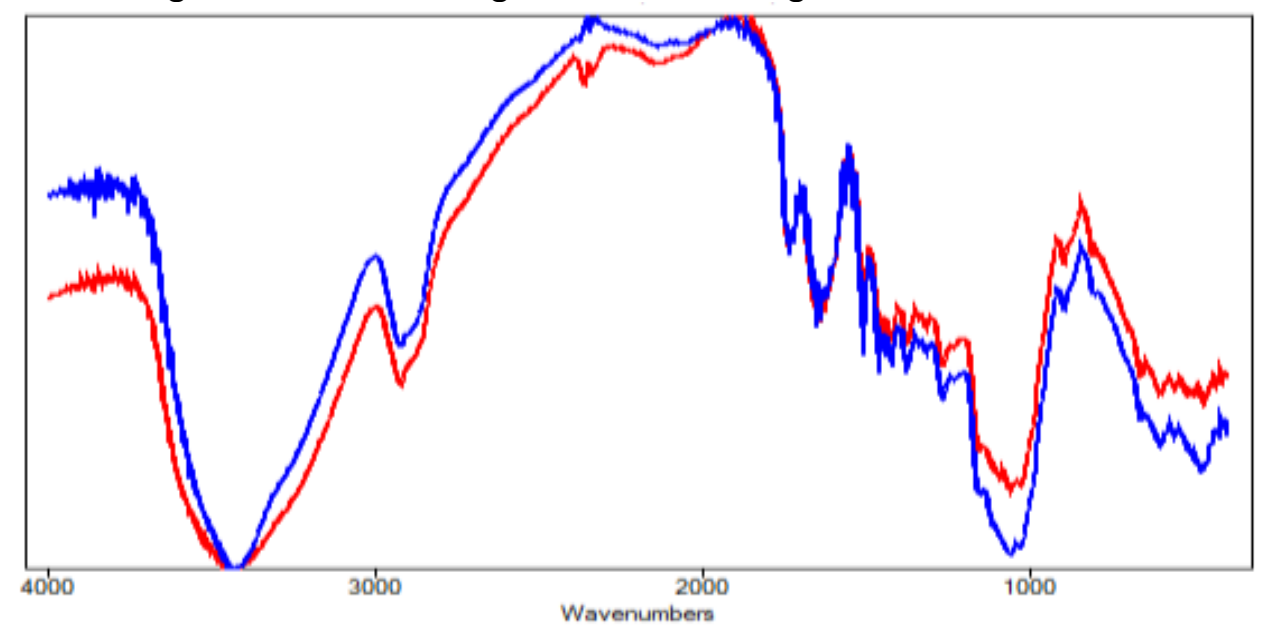

Figure (11) FT-IR spectra of wood sample treated by lavender oil with indirectapplication for ten days that revealed loss at water content according to $\mathrm{OH}$ stretching and increasing at cellulose polymerization

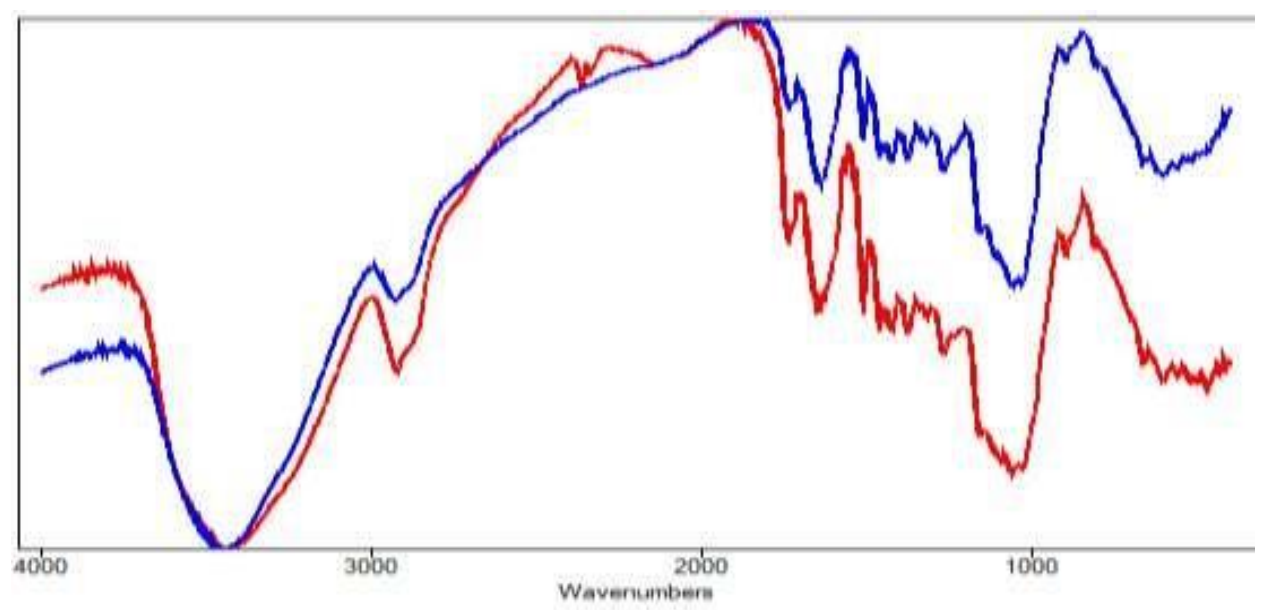


Figure (12) FT-IR spectra of wood sample treated by thyme oil with direct application Revealed simple decreasing at oxidation of cellulose, hemicellulose and polymerization

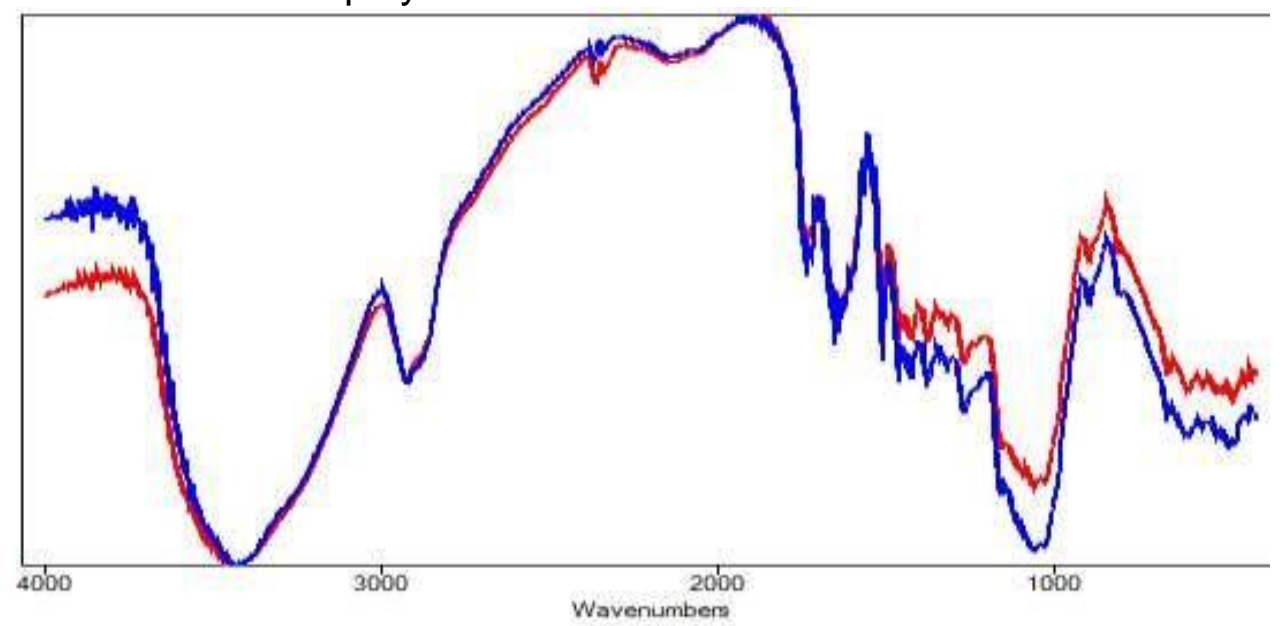

Figure (13) FT-IR spectra of wood sample treated by thyme oil with indirect application for five days revealed increasing at cellulose polymerization

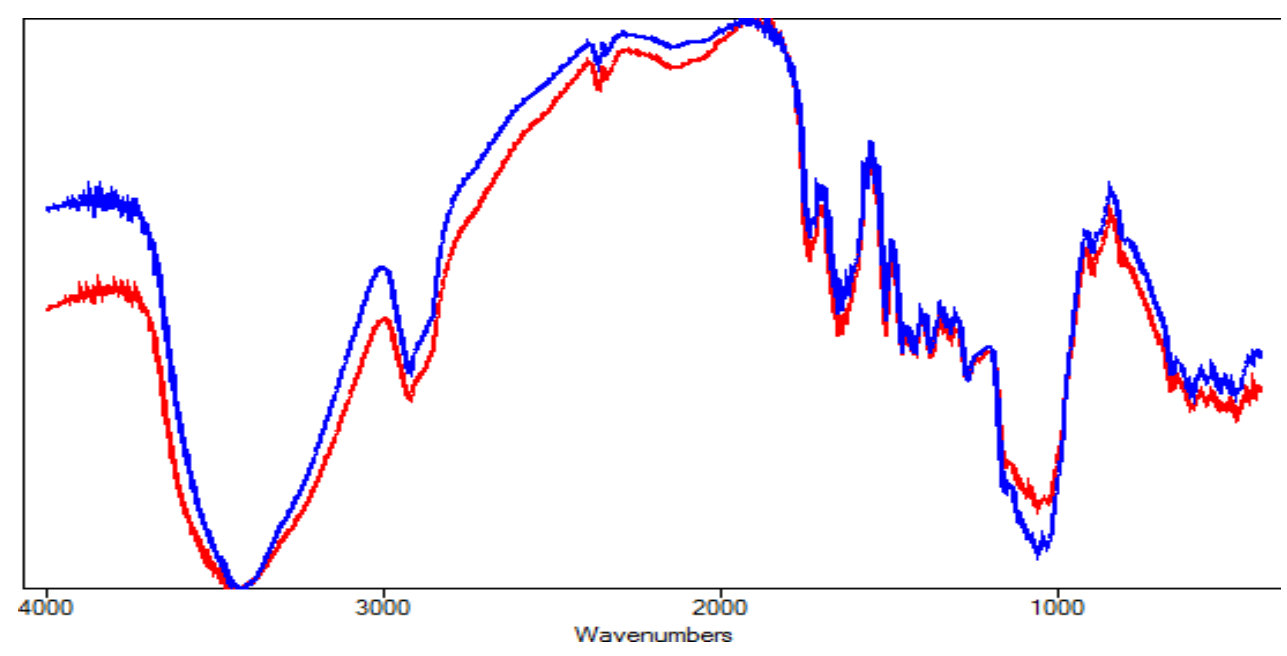


Figure (14) FT-IR spectra of wood sample treated by thyme oil with indirect application for ten days simple loss at water content at $\mathrm{OH}$ stretching and increasing at polymerization

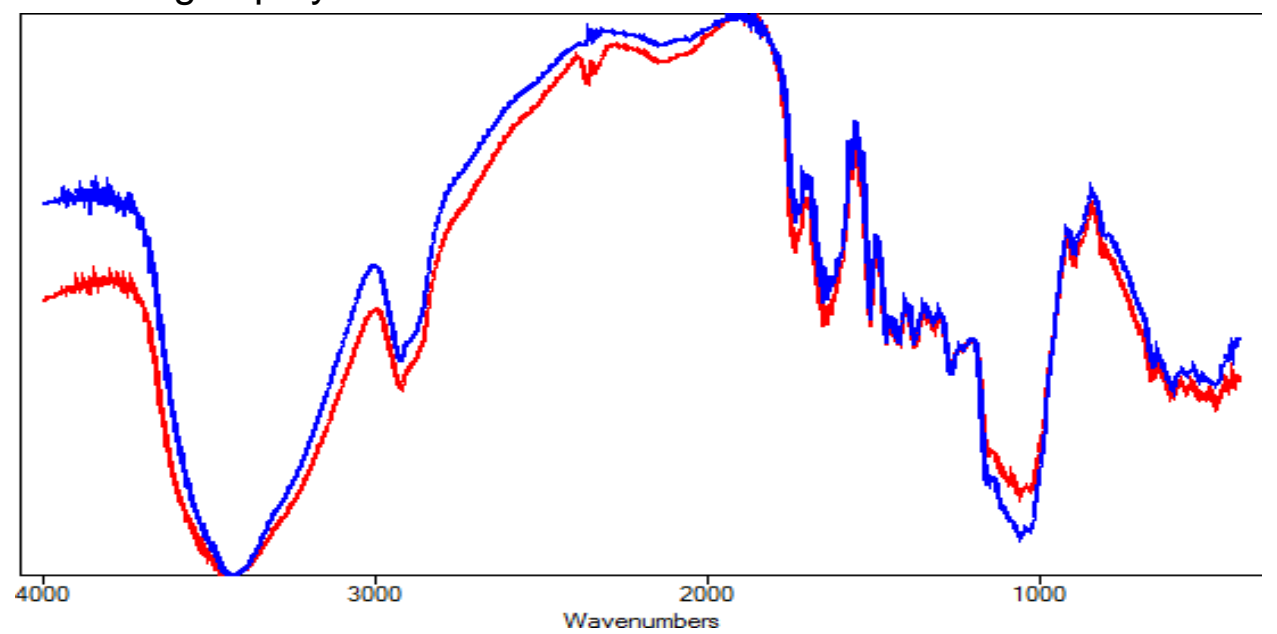

Figure (15) FT-IR spectra of wood sample treated by nanosilver oil with direct application revealed simple loss at water content and simple increasing atpolymerization

The profile of FTIR spectra were very similar before and after treatment whereas the intensity of peaks was different to some extent. All types of oils affect oxidation of cellulose, thyme and lemon oil not stable by aging that lead to increasing at changesby age. The most stable was lavender oil and nanosilver just small loss at water content. 
3.3. application of indirect method at object from manial museum
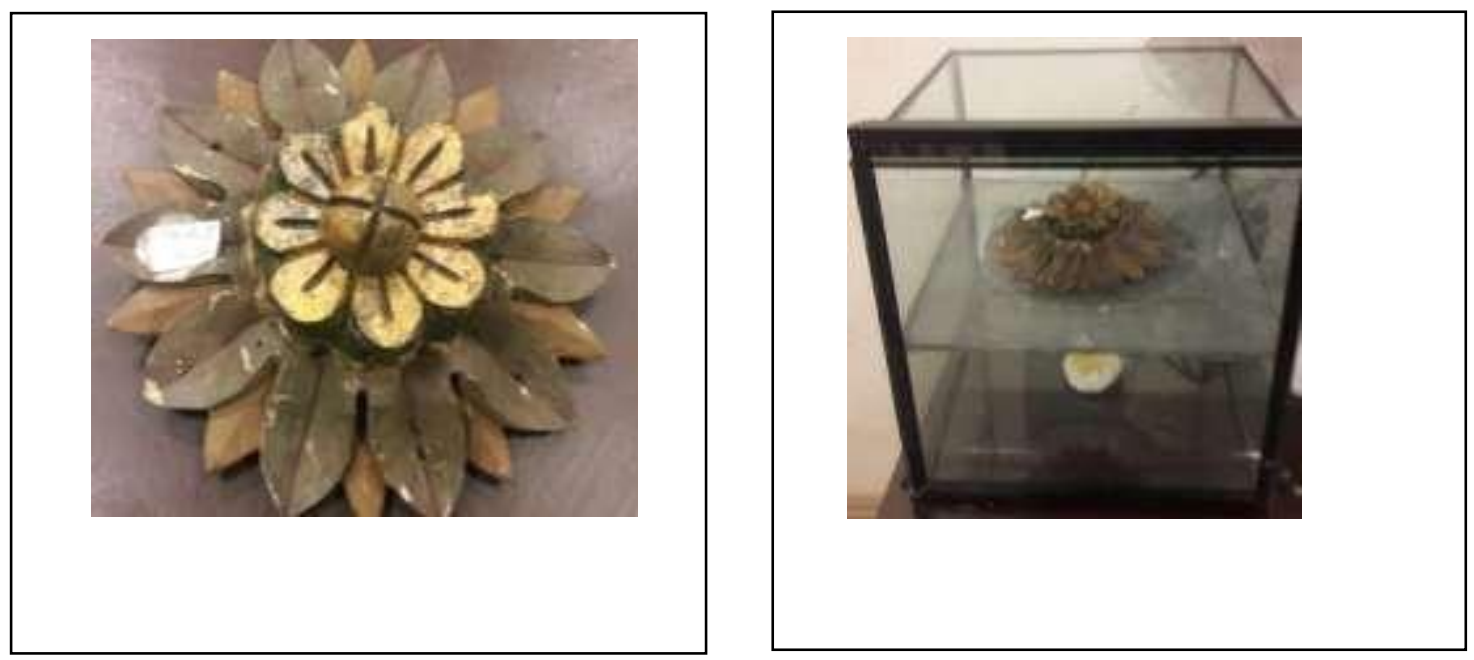

The indirect method was applied on object number 754 from EIManial museum by using lavender oil for 24 hours.

\section{Conclusion:}

This work presents Comparison between the Effect of Essential Oil and Nano-silver used in Wood Sterilization in Chemical Composition and visual properties of Wood by using FTIR spectroscopy is an established technique for determining the chemical composition of wood to identify the changes at chemical composition by function groups that revealed small loss at water content of wood at lavender oil even in direct or indirect application and increasing at polymerization at indirect application for ten days. And increasing with very small amount at polymerization of celluse at nanosilver treatment and lemon oil with indirect application for five days also all applications of thyme oil leads to that increasing at polymerization, all types of oils affected the oxidation of cellulose, nanosilver proved it is stability and efficiency on sterilization with the lowest changes. By colorimetric measurement revealed changes at all essential oils direct application and at lemon and thyme oil at indirect application. By microscopic inspection shows that all essential oils at direct application before and after using direct application of all three essential oils and the most dangerous one is lemonoil should be avoided that because of it is unstable causing increasing at changes by age but thyme oil caused less changes compared 
to lemon oil but it become unstable by aging so also it should be avoided, the safest essential oil is lavender oil by indirectmethod because of it is stability and nanosilver by direct method.

\section{References}

1.Ghica, A. G., Alley, V., \& laşi. (2007). Fourier Transform Infrard Spectroscopy And Thermal Analysis Of Lignocellulose Fillers Treated With Organic Anhydrides. "Petru Poni" Institute of Macromolecular Chemistry, 1-12.

2.Lionetto, F., Sole, R. D., Cannoletta, D., Vasapollo, G., \& Maffezzoli, A. (2012). Monitoring Wood Degradation during Weathering by Cellulose Crystallinity. materials, 1910-1922.

3. Naumann, A., \& Kües, U. (2007, January). Fourier Transform Infrared Microscopy

Wood Analysis. Retrieved from Reseach ate:http://www.researchgate.net/publication/262179733

4.Poletto, M., Zattera, A. J., \& Santana, R. M. (2012, April 15). Structural Differences Between Wood Species: Evidence from Chemical Composition, FTIR Spectroscopy, and Thermogravimetric Analysis. Retrieved from Wiley Online Library: wileyonlinelibrary.com

5. Ahmed, K. M.-S. (2018). Experimental study on the evaluation of Nano materials used in the treatment and conservation of microbiologically infested archaeological hardwoods. cairo: Cairo University Faculty of arhaeology.

6. Bahmani, M., \& Schmidt, O. (2018). Plant Essential Oils For EnvironmentFrindley Protection Of Wood Object Against Fungi. Ciencia y tecnología, 325 - 332.

7.Cavanagh, \& Wilkinson. (2002). Biological Activities of Lavender Essential Oil.

Phytotherapy Research, 301-308. 
8.D, W., J, S., JP, Ż., \& E, M. (2016). The Antifungal Properties of Peppermint and Thyme Essential Oils Misted in Broiler Houses. Brazilian Journal of Poultry Science, 629-637.

9.G. G., V. A., \& Iaşi. (2007). Fourier Transform Inferared Spectrocsopy And Thermal Analysis Of Lignocellulose Fillers Treated With Organic Anhydrides. "Petru Poni", 1-12.

10. Kim, S. W., Jung, J. H., Lamsal, K., Kim, Y. S., Min, J. S., \& Lee, Y. S. (2012).

Antifungal Effects of Silver Nanoparticles (AgNPs) against Various PlantPathogenic Fungi. Research Article, 1-58.

11. Kocaefe, D., Huang, X., Kocaefe, Y., \& Boluk, Y. (2013). Study on Weathering Behavior of Jack Pine Heat-Treated under Different Conditions. Energy and Power Engineering, 818-826.

12. Lucas, G. C., Alves, E., Pereira, R. B., Perina, F. J., \& de Souza, R. M. (2012). Antibacterial activity of essential oils on Xanthomonas vesicatoria and control of bacterial spot in tomato. Universidade Federal de Lavras, Departamento deFitopatologia, 351-359.

13. Lykidis, C., Bak, M., Mantanis, G., \& Németh, R. (2016). Biological resistance of pine wood treated with nano-sized zinc oxide and zinc borate against brown- rot fungi. Springer, 1-5.

14. Naik, M. I., Fomda, B. A., Jaykumar, E., \& Bhat, J. A. (2010). Antibacterial Activity Of Lemongrass (Cymbopogon citratus) Oil Against Some Selected Pathogenic Bacterias. Asian Pacific Journal of Tropical Medicine, 535-538.

15. Oeno, R. (2006). Determination of chromatic characteristics according to CIELab.

Compendium Of International Analysis Of Methods - OIV , 1-16.

16. Rad, J. S., Sureda, A., Tenore, G. C., Daglia, M., Rad, M. S., Valussi, M., .. . Iriti, M. (2017). Biological Activities of Essential Oils: From Plant 
Chemoecology to Traditional Healing Systems. molecules, 1-55.

17. Reinprecht, L., I'zdinsk'y, J., \& Vidholdov'a, Z. (2018). Biological Resistance and Application Properties of Particleboards Containing Nano-Zinc Oxide. Hindawi, 1-8.

18. Reinprecht, L., Vidholdová, Z., \& Gašpar, F. (2016). Decay Inhibition Of Maple Wood With Nano-Zinc Oxide Used In Combination With Essential Oils. Acta Facul Tatis Xylologiae Zvolen, 1-58.

19. rezaei, V. T., Usefi, A., \& Soltani, M. (2011). Wood protection by nano silver against white rot. 5th SASTech, Khavaran Higher-education Institute, 1-7.

20. Sahin, T., \& Mantanis, G. (2011). Nano-Based Surface Treatment Effects On Swelling,Water Sorption And Hardness Of Wood. Ciencia y tecnología, 1-48.

21. Seow, Y. X., Yeo, C. R., Chung, H. L., \& Yuk, H. G. (2013). Plant Essential Oils as Active Antimicrobial Agents. Critical Reviews in Food Science and Nutrition, 625-644.

22. Soad, Dalia, \& s, D. (n.d.). Comparing the Antimicrobial Activity of Three Essential Oils against Microorganisms Most Commonly Encountered in Necrotic Root Canal Systems. E.D.J, 1-6.

23. Taghiyari, H. R. (2014). Nanotechnology in Wood and Wood-Composite Materials. Journal of Nanomaterials \& Molecular Nanotechnology, 1-2.

24. Vina, \& Carol. (2007). Inhibitory Effect of Essential Oils on Decay Fungi and Mold Growth on Wood. American Wood Protection Assosiation, 62-70.

25. Wong, Mudzaqqir, A., \& Nurdiyana, W. (2014). Extraction of Essential Oil from Cinnamon (Cinnamomum zeylanicum). Oriental Journal of Chemistry, 37-47. 
INTERNATIONAL JOURNAL OF MULTIDISCIPLINARY STUDIES IN ARCHITECTURE AND CULTURAL HERITAGE

ISSN: 2735-4415
VOLUME 2, ISSUE 1, 2019, 1-30.

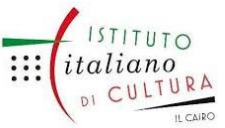

www.egyptfuture.org/ojs/

Received: February 15, 2018

Accepted: April 20, 2018 